\title{
Karakteristik Morfologi dan Fisiologi Isolat Pantoea stewartii subsp. stewartii pada Jagung
}

\author{
Morphological dan Physiological Characterization of \\ Pantoea stewartii subsp. stewartii from Maize \\ Yulfi Desi $^{{ }^{*}}$, Trimurti Habazar ${ }^{2}$, Agustian $^{2}$, Ujang Khairul ${ }^{2}$, Syamsuwirman $^{2}$, Prima Novia $^{2}$ \\ ${ }^{1}$ Universitas Ekasakti, Padang 25113 \\ ${ }^{2}$ Universitas Andalas, Padang 25163
}

\begin{abstract}
ABSTRAK
Pantoea stewartii subsp. stewartii adalah patogen penyebab penyakit layu stewart pada tanaman jagung yang baru diketahui keberadaannya di Indonesia. Keberadaan patogen ini telah dilaporkan terdapat pada beberapa daerah, namun belum banyak laporan penelitian terkait masalah ini. Penelitian bertujuan mencirikan isolat $P$. stewartii subsp. stewartii dari beberapa sentra pertanaman jagung di Sumatra Barat. Isolat-isolat $P$. stewartii subsp. stewartii berasal dari tanaman jagung yang menunjukkan penyakit layu stewart di 6 kabupaten di Sumatera Barat. Daun tanaman jagung yang mempunyai gejala garis kuning sepanjang tulang daun digerus dan disuspensikan, selanjutnya bakterinya diisolasi pada medium nutrient glucose agar $(\mathrm{NGA})$ dan diinkubasi selama $3 \times 24$ jam pada suhu kamar. Karakter yang diuji ialah morfologi dan fisiologi bakteri, hipersensitivitas, patogenisitas, dan uji polymorfism chain reaction. Berdasarkan karakter morfologi dan fisiologi didapatkan 7 isolat yang menunjukkan karakter Pantoea. Hasil uji PCR membuktikan bahwa isolat LA homolog dengan Pantoea stewartii galur R1-104, isolat PR1 homolog dengan Pantoea stewartii galur R1-132, dan isolat PR2 homolog dengan Pantoea stewartii galur ATCC 29923.
\end{abstract}

Kata kunci: identifikasi, karakterisasi, layu stewart

\begin{abstract}
Pantoea stewartii subsp. stewartii is the pathogen causing stewart's wilt disease in maize. The occurrence of the disease was recently reported in Indonesia with limited information. Research was conducted to characterize several isolates of $P$. stewartii subsp. stewartii isolated from maize plants collected from 6 districts in West Sumatra. Leaves showing yellow stripes symptoms along the vein was ground and suspeneded then the bacteria was isolated and incubated for $3 \times 24 \mathrm{~h}$ at room temperature in nutrient glucose agar (NGA). Pure bacterial colonies gained from this medium was used for characterization. Assessment of bacterial characters was conducted based on morphological assay, physiological assay, biological assay (hypersensitivity, and pathogenicity) followed by polymerase chain reaction (PCR)-based identification. Unique characters of the family Enterobacteriaceae was observed on 7 isolates based on morphological and physiological characters, and only 4 isolates (PR1, PP, ST1, LA) gave positive reaction on hypersensitivity and pathogenicity test. Further molecular identification confirmed 3 out of 7 isolates had high homology to Pantoea stewartii, i.e. Pantoea stewartii strain R1104, R1-132, and ATCC 29923 for isolates LA, PR1, and PR2, respectively.
\end{abstract}

Key words: characterization, identification, stewart's wilt

*Alamat penulis korespondensi: Fakultas Pertanian, Universitas Ekasakti Padang, Jalan Veteran Dalam 26 B, Padang 25113 Tel: 0751-28859/26770, Faks: 0751-32694, Surel: yulfi.desi@yahoo.com 


\section{PENDAHULUAN}

Penyakit layu stewart pada tanaman jagung disebabkan oleh bakteri Pantoea stewartii subsp. stewartii. Sampai saat ini informasi mengenai keberadaan penyakit layu ini di Indonesia masih terbatas. Beberapa penelitian terkait $P$. stewartii subsp. stewartii telah dilakukan oleh Trisnawati (2010) dan Rahma (2013).

Spesies dari genus Pantoea dicirikan berdasarkan morfologi koloni, uji fisiologi, biokimia, analisis asam lemak, dan komposisi quinon. Bodman dan Farrand (1995) melakukan uji ß-galactosidase, biosintesis EPS, CAT assay, dan produksi acyl homoserine lactone (AHL). TAS (2008) menetapkan beberapa karakter fisiologi antara lain: pergerakan bakteri, sifat Gram, metabolisme glukosa, oksidasi, katalase, hidrolisis esculin, produksi acetion, produksi indol, reduksi nitrat, pertumbuhan pada cis-anonitate, produksi asam (maltose, arbutin, raffinose, cellubiose, dan arabitol).

Penelitian bertujuan mencirikan isolat bakteri $P$. stewartii subsp. stewartii dari beberapa sentra pertanaman jagung di Sumatra Barat.

\section{BAHAN DAN METODE}

\section{Sumber Tanaman Sakit}

Bahan tanaman sakit berasal dari beberapa sentra pertanaman jagung di Sumatra Barat, yaitu Kabupaten Agam (Gadut dan Lubuk Basung), Kabupaten Pasaman Barat (Padang Tujuh dan Padang Rajo), Kabupaten Lima Puluh Kota (Simalanggang dan Tanjung Pati), Kabupaten Tanah Datar (Kumanggo dan Sumaniak), Kabupaten Padang Pariaman (Lubuk Alung dan Ketaping), dan Kota Padang (Pauh dan Kuranji). Daun tanaman jagung yang bergejala garis kuning sepanjang tulang daun dipotong dengan ukuran $1.5 \mathrm{~cm} \mathrm{x}$ $7 \mathrm{~cm}$, kemudian dibilas dengan akuades steril, alkohol 70\%, dan akuades steril kembali, selanjutnya digerus dengan $10 \mathrm{~mL}$ akuades steril menggunakan lumpang steril. Suspensi bakteri diencerkan sampai $10^{-6}$ dan sebanyak
$100 \mu \mathrm{L}$ dituangkan pada medium nutrient glucose agar (NGA), selanjutnya diinkubasi selama $3 \times 24$ jam pada suhu kamar. Komposisi NGA ialah 28 g agar-agar nutrien ditambah 10 g glukosa, dan $1000 \mathrm{~mL}$ akuades. Koloni bakteri yang menunjukkan karakter $P$. stewartii subsp. stewartii: berwarna kuning, berkilat, berlendir, datar atau cembung. Isolat murni dimasukkan ke dalam tabung berisi akuades steril, divorteks dan disimpan di dalam lemari pendingin.

\section{Uji Morfologi}

Uji morfologi koloni bakteri yang diamati mengikuti Cappucino dan Sherman (2002) terhadap warna koloni (kuning, kuning pucat), ukuran koloni (kecil, sedang, besar), bentuk koloni (bulat, tidak beraturan, tersebar), keadaan koloni (berlendir, tidak berlendir), dan bentuk pinggiran koloni (rata, bergelombang).

\section{Uji Gram}

Uji Gram dilakukan untuk membedakan kelompok bakteri berdasarkan ketebalan dinding sel. Sebanyak $10 \mu \mathrm{L}$ KOH 3\% diteteskan pada kaca objek, sejumlah sel dari koloni bakteri dipindahkan dengan jarum ose, diaduk sampai sempurna kira-kira pada diameter $1.5 \mathrm{~cm}$. Jika ujung jarum ose diangkat ke atas dan suspensi menjadi berlendir dalam waktu 5-60 detik maka isolat bakteri tersebut ialah Gram negatif. Sebaliknya, jika tidak terbentuk lendir maka isolat tersebut merupakan bakteri Gram positif.

\section{Uji Katalase}

Uji katalase dilakukan untuk membantu identifikasi bakteri tergolong Enterobacteriaceae (Taylor dan Anhanzar 1972). Setetes $\mathrm{H}_{2} \mathrm{O}_{2}$ ditempatkan pada gelas objek, isolat uji dioleskan secara merata menggunakan tusuk gigi steril, ditetesi kembali dengan 10 tetes $\mathrm{H}_{2} \mathrm{O}_{2}$ apabila muncul gelembung gas berarti menunjukkan reaksi positif $(+)$, sebaliknya apabila tidak terdapat gelembung gas berarti menunjukkan reaksi negatif (-). Bakteri yang tergolong Enterobacteriaceae menunjukkan reaksi positif $(+)$. 


\section{Uji Oksidasi}

Uji oksidasi adalah pengujian yang digunakan untuk menentukan apakah bakteri menghasilkan sitokrom-C oksidase tertentu. Uji oksidasi dilakukan menggunakan strip oxidase test. Isolat uji digoreskan pada strip oxidase test, munculnya warna biru setelah beberapa detik menunjukkan terjadinya reduksi atau bereaksi negatif (-), apabila tidak menimbulkan warna biru berarti terjadi oksidasi atau bereaksi positif $(+)$.

\section{Uji Metabolisme Glukosa}

Salah satu medium yang dapat digunakan untuk identifikasi bakteri genus Pantoea ialah medium hugh-leifson (HL). Komposisi medium HL terdiri atas larutan utama dan larutan glukosa. Larutan utama terdiri atas $20 \mathrm{~g}$ peptone, $5 \mathrm{~g} \mathrm{NaCl}, 0.3 \mathrm{~g} \mathrm{KH}_{2} \mathrm{PO}_{4}$, $3 \mathrm{~g}$ agar-agar, $3 \mathrm{~mL}$ bromotimol biru $1 \%$. Larutan glukosa terdiri atas $10 \mathrm{~g}$ glukosa dan $60 \mathrm{~mL} \mathrm{dH}_{2} \mathrm{O}$. Medium ini digunakan untuk mengetahui isolat yang mampu menghasilkan glukosa secara anaerob. Pelaksanaan metabolisme glukosa dilakukan mengikuti prosedur sebagai berikut. Medium HL steril dimasukkan ke dalam tabung, kira-kira 2/3 bagian, kemudian isolat uji diinokulasikan pada 2 tabung (A dan B). Permukaan medium ditutup dengan menuangkan 1-2 $\mathrm{mL}$ vaselin steril. Munculnya warna kuning pada tabung dalam waktu 24 jam pada suhu $27{ }^{\circ} \mathrm{C}$ menunjukkan reaksi positif $(+)$ dan warna biru menunjukkan reaksi negatif $(-)$.

\section{Deteksi Produksi Acyl Homoserine Lactone}

Deteksi produksi acyl homocerine lactone (AHL) didasarkan pada metode Bodman dan Farrand (1995). Medium yang digunakan ialah medium minimal (MM) mengandung $40 \mu \mathrm{g}$ X-Gal (5-bromo-4chloro-3indolyl- $\beta$ - $d$ galactocidase) $\mathrm{mL}^{-1}$ dan galur indikator yang digunakan adalah Agrobacterium tumefaciens A4404 yang diperoleh dari Laboratorium Bioteknologi dan Pemuliaan Tanaman, Fakultas Pertanian, Universitas Andalas. Isolat uji digoreskan, kemudian galur indikator digoreskan lagi membentuk dua garis sejajar. Setelah biakan diinkubasi pada suhu $28{ }^{\circ} \mathrm{C}$ akan terbentuk zone warna biru.

\section{Deteksi Exopolisaccharide Substance Stewartan}

Deteksi exopolisaccharide substance stewartan (EPS) didasarkan pada metode Bodman dan Farrand (1995). Isolat uji ditumbuhkan pada medium casamino acid peptone glucose (CPG) dengan komposisi glukosa $1 \%$, tripton $1 \%$, casamino acid $0.1 \%$, dan agar-agar $1.5 \%$. Sel bakteri dari biakan diambil dan dimasukkan ke dalam $10 \mathrm{~mL}$ larutan $\mathrm{NaCl} 0.9 \%$. Campuran larutan tadi dipindahkan ke dalam gelas piala dan diputar dengan cepat selama 1 menit menggunakan stirer, seterusnya disentrifugasi selama 30 menit. Supernatan dipisahkan dan dipindahkan ke dalam gelas piala lalu ditambahkan $60 \mathrm{~mL}$ etil alkohol, kemudian ditempatkan di dalam ruang pendingin selama 1 malam. Sisa pelet dicuci dengan $1 \mathrm{~mL} \mathrm{NaCl} 0.9 \%$ per tabung. Semua ekstrak dipindahkan ke gelas piala lalu ditambahkan $60 \mathrm{~mL}$ etil alkohol dan disimpan selama 24 jam di dalam ruang pendingin. Ekstrak EPS diambil dan dicuci dengan air steril, seterusnya disimpan di dalamlemari pembeku sampai waktu yang diinginkan.

\section{Uji Adhesi}

Uji adhesi dilakukan berdasarkan pada metode O'Toole dan Kolter (Koutsoudis et al. 2006). Isolat uji ditumbuhkan pada medium luria bertani (LB) yang mengandung glukosa $0.2 \%$. Pengujian adhesi menggunakan kotak plastik polivinil klorida yang mempunyai 5 sumur. Isolat uji dicuci berulang kali dan diwarnai dengan kristal violet $1 \%$ selama 15 menit pada suhu kamar. Sisa zat warna dipisahkan melalui pencucian dengan akuades mengalir, sisa kristal violet dilarutkan dalam $150 \mu \mathrm{L}$ etanol $95 \%$ yang ditambahkan pada setiap sumur. Pengujian ini ditujukan untuk mengetahui tegangan permukaan dari sel bakteri. Pada kesempatan ini hasil uji tidak dapat dilanjutkan karena tidak tersedianya tensiometer.

\section{Uji Patogenisitas}

Uji patogenisitas dilakukan pada bibit jagung varietas Sweet Boy umur 8 hari. Isolat yang terdeteksi sebagai Gram negatif (-)

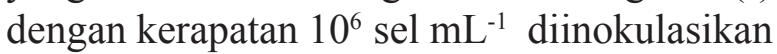


menggunakan jarum steril pada batang bibit kira-kira $5 \mathrm{~cm}$ dari permukaan tanah. Gejala kebasahan akan muncul setelah 3 hari dan bibit menunjukkan gejala layu antara 5-8 hari setelah inokulasi.

\section{Uji Hipersensitivitas}

Uji hipersensitifitas dilakukan untuk mengetahui kemampuan isolat dalam menimbulkan gejala respons hipersensitif. Isolat yang terdeteksi sebagai bakteri Gram negatif dengan kerapatan $10^{8}$ sel $\mathrm{mL}^{-1}$ diinfiltrasikan menggunakan jarum steril pada daun tembakau, kemudian tanaman disungkup dengan kantong plastik. Gejala akan muncul dalam waktu 24 jam setelah infiltrasi.

\section{Uji Polymerase Chain Reaction}

Isolat yang akan diuji ditumbuhkan pada medium yeast dextrose carbonate (YDC) selama 48 jam pada suhu $23^{\circ} \mathrm{C}, 5 \mu \mathrm{L}$ suspensi sel bakteri di dalam akuades steril ditambah dengan $50 \mu \mathrm{L} \mathrm{NaOH} 0.05 \mathrm{M}$ dan selnya dilisis pada penangas air yang mendidih selama 15 menit. Sebanyak $5 \mu \mathrm{L}$ hasil lisis tersebut ditambahkan ke $45 \mu \mathrm{L}$ campuran reaktan yang terdiri atas $1 \mathrm{x}$ bufer reksi, $\mathrm{MgCb} 1.5 \mathrm{mM}$, dNTP's masing-masing $200 \mu \mathrm{M}$ (Boehringer Mannheim), primer masing-masing $1 \mu \mathrm{M}$ dan 2.50 unit AmpliTaq DNA polymerase. Amplifikasi DNA dilakukan menggunakan pasangan primer ES16: 5'-GCG AAC TTG GCA GAG AT-3' dan ESIG2c: 5'-GCG CTT G TGTTAT GAG-3' didahului dengan denaturasi awal selama 5 menit pada $94^{\circ} \mathrm{C}$, dilanjutkan sebanyak 35 siklus meliputi denaturasi selama 1 menit pada $94^{\circ} \mathrm{C}$, penempelan primer selama 1 menit pada $55^{\circ} \mathrm{C}$ sintesis selama 2 menit pada $72{ }^{\circ} \mathrm{C}$, pada tahapan terakhir ditambah 10 menit pada $72{ }^{\circ} \mathrm{C}$. Hasil amplifikasi dielektroforesis menggunakan gel agaros $1 \%$ dalam bufer tris boric EDTA (TBE 0.5 $\mathrm{x})$ dan divisualisasi menggunakan UV. Pola pita DNA masing-masing isolat diamati untuk mengetahui keragaman isolat. Selanjutnya dilakukan sikuensing terhadap isolat tersebut dan perunutan DNA menggunakan program NCBI BLAST (http://www.ncbi.nlm.nih.gov/ BLAST).

\section{HASIL}

\section{Gejala Penyakit di Lapangan}

Gejala penyakit yang ditemui pada beberapa pertanaman jagung di Sumatra Barat sangat beragam, di antaranya ialah terdapat garis-garis tegas berwarna kuning sepanjang pertulangan daun, pinggiran daun bergelombang, tanaman kerdil, dan daun mengering lebih cepat.

\section{Morfologi Isolat Bakteri}

Isolasi bakteri dari daun bergejala garis kuning sepanjang tulang daun didapatkan 22 isolat murni. Pada medium NGA, bakteri mempunyai ciri bentuk koloni bulat, warna koloni kuning terang dan kuning, ukuran koloni berkisar antara 1 dan $4 \mathrm{~mm}$, elevasi cembung, keadaan koloni berlendir, dan pinggiran koloni bervariasi (Tabel 1).

\section{Uji Fisiologi}

Hasil uji Gram yang dilakukan terhadap 22 isolat murni diperoleh 10 isolat merupakan bakteri Gram negatif dan 10 isolat bakteri Gram positif, sementara dua isolat tidak diuji karena tidak menghasilkan pigmen kuning pada media NGA. Sebanyak 7 isolat bereaksi positif $(+)$ pada uji katalase dan uji metabolisme glukosa tetapi bereaksi negatif (-) pada uji oksidasi. Oleh karena itu, uji lanjut hanya dilakukan terhadap 7 isolat ini (Tabel 2).

\section{Uji Hipersensitivitas dan Patogenisitas}

Uji hipersensitivitas (HS) pada tanaman tembakau, menunjukkan reaksi positif hanya pada 4 isolat, yaitu PR1, PP, ST1, dan LA, sedangkan 6 isolat lainnya menunjukkan reaksi negatif.

Uji patogenisitas yang dilakukan terhadap bibit jagung varietas Sweet Boy menghasilkan variasi gejala. Isolat $\mathrm{KP} 1, \mathrm{KP} 3$, dan PR2 menunjukkan gejala daun menguning mulai dari bawah, kemudian berwarna cokelat dan akhirnya tanaman layu dan mati. Isolat PT1, PR1, PP, LA, dan PT3 menunjukkan gejala water soaking dan pada hari ke-4 tanaman layu, sedangkan isolat ST1 dan ST3 menunjukkan 
Tabel 1 Morfologi isolat Pantoea stewartii subsp. stewartii dari beberapa sentra pertanaman jagung di Sumatera Barat

\begin{tabular}{llccll}
\hline \multirow{2}{*}{$\begin{array}{l}\text { Isolat } \\
\text { bakteri }\end{array}$} & Bentuk & Warna & $\begin{array}{c}\text { Ukuran } \\
(\mathrm{mm})\end{array}$ & Keadaan & Pinggiran \\
\cline { 2 - 6 } KP1 & Tidak teratur & Kuning terang & $3-4$ & Berlendir & Undulate \\
PT1 & Tidak teratur & Kuning terang & $3-4$ & Berlendir & Undulate \\
KP3 & Tidak teratur & Kuning terang & $2-3$ & Berlendir & Undulate \\
PR1 & Melingkar & Kuning terang & $1-2$ & Berlendir & Entire \\
PP & Melingkar & Kuning pucat & $1-2$ & Berlendir & Entire \\
ST1 & Tidak teratur & Kuning pucat & $1-2$ & Berlendir & Undulate \\
LA & Melingkar & Kuning terang & $2-3$ & Berlendir & Entire \\
PT3 & Melingkar & Kuning terang & $2-3$ & Berlendir & Entire \\
ST3 & Tidak teratur & Kuning pucat & $1-2$ & Berlendir & Undulate \\
PR2 & Melingkar & Kuning terang & $2-3$ & Berlendir & Entire \\
\hline
\end{tabular}

KP1, Kampung Periuk 1; PT1, Padang Tujuh 1; PR1, Padang Rajo 1; KP3, Kampung Periuk 3; PP, Pauh Padang; ST1, Simpang Tiga 1; LA, Lubuk Alung; PT3, Padang Tujuh 3; ST3, Simpang Tiga 3; PR2, Padang Rajo 2.

Tabel 2 Hasil uji fisiologi isolat bakteri Pantoea stewartii subsp. stewartii dari beberapa sentra pertanaman jagung di Sumatera Barat

\begin{tabular}{lccccccccc}
\hline Isolat & Gram & Katalase & Oksidasi & $\begin{array}{c}\text { Meta } \\
\text { glukosa }\end{array}$ & AHL & EPS & Adhesi & $\begin{array}{c}\text { Patogeni } \\
\text { sitas }\end{array}$ & HR \\
\hline KP1 & - & + & - & + & 1 & 2 & 1 & + & - \\
PT1 & - & + & - & + & 0 & 1 & 2 & + & - \\
KP3 & - & - & $\ldots$ & $\ldots$ & $\ldots$ & $\ldots$ & $\ldots$ & + & - \\
PR1 & - & + & - & + & 1 & 1 & 2 & + & + \\
PP & - & + & - & + & 4 & 1 & 1 & + & + \\
ST1 & - & - & $\ldots$ & $\ldots$ & $\ldots$ & $\ldots$ & $\ldots$ & - & + \\
LA & - & + & - & + & 2 & 2 & 2 & + & + \\
PT3 & - & + & - & + & 0 & 3 & 4 & + & - \\
ST3 & - & - & $\ldots$ & $\ldots$ & $\ldots$ & $\ldots$ & $\ldots$ & - & - \\
PR2 & - & + & - & + & 2 & 1 & 3 & + & - \\
\hline
\end{tabular}

KP1, Kampung Periuk 1; PT1, Padang Tujuh 1; KP3, Kampung Periuk 3; PR1, Padang Rajo 1; PP, Pauh Padang; ST1, Simpang Tiga 1; LA, Lubuk Alung; PT3, Padang Tujuh 3; ST3, Simpang Tiga 3; PR2, Padang Rajo 2; AHL, acyl homocerine lactone; EPS, exopolisaccharide substance stewartan +, bereaksi positif; -, bereaksi negatif; 0 , tidak ada; 1 , sedikit; 2 , sedang; 3 , cukup; 4 , banyak; ..., tidak dilakukan. 
gejala daun menguning yang dimulai dari bagian ujung, kemudian berwarna cokelat dan tanaman tidak layu.

\section{Uji Polymerase Chain Reaction}

Dari uji morfologi, fisiologi, dan patogenisitas diperoleh tujuh isolat menunjukkan karakter Pantoea. Selanjutnya, identifikasi isolat tersebut menggunakan polymerase chain reaction (PCR) dengan pasangan primer ES16 dan ESIG2C (Gambar $3)$.

Hasil analisis urutan basa nukleotida menunjukkan bahwa tidak semua isolat tergolong genus Pantoea, hanya empat isolat diantaranya sebagai genus Pantoea dan tiga isolat sebagai spesies Pantoea stewartii yakni: isolat dari Padang Rajo 2, Lubuk Alung dan Pdang Rajo 1 memiliki kemiripan 98\% asesi no. FJ118651, JQ6595401 dan JQ6595451 (Tabel 3).

\section{PEMBAHASAN}

Gejala penyakit layu stewart yang ditemukan pada beberapa sentra pertanaman jagung di Sumatera Barat sangat beragam. Gejala penyakit sesuai dengan yang dikemukakan oleh EPPO (2006), yaitu daun-daun bagian bawah awalnya memiliki garis-garis berwarna kuning. Penyakit ini berbeda dengan penyakit hawar yang umumnya menyebabkan warna daun-daunnya berkembang menjadi hijau pucat sampai kuning, terdapat garis longitudinal, dengan pinggiran tidak teratur atau bergelombang, dan dapat memanjang di sepanjang helaian daun, garis-garis ini mengering kemudian bewarna cokelat.

Uji katalase menunjukkan bahwa tujuh isolat menghasilkan gelembung atau bereaksi positif (+) dan tiga isolat bereaksi negatif (-).

Tabel 3 Analisis homologi sekuen DNA dari 3 isolat bakteri dari daun jagung bergejala penyakit layu stewart di sentra pertanaman jagung Sumatera Barat

\begin{tabular}{lcccc}
\hline Isolat & $\begin{array}{c}\text { Panjang sekuen DNA } \\
(\mathrm{pb})\end{array}$ & $\begin{array}{c}\text { Homologi sekuen 16S RNA } \\
\text { Pantoea stewartii }\end{array}$ & $\begin{array}{c}\text { Homologi } \\
\%\end{array}$ & $\begin{array}{c}\text { Kode aksesi } \\
\text { GenBank }\end{array}$ \\
\hline PR2 & 1408 & galur ATCC 29923 & 98 & FJ6118651 \\
LA & 902 & galur R1-104 & 96 & JQ6595401 \\
PR1 & 775 & galur R1-132 & 94 & JQ6595451 \\
\hline
\end{tabular}

PR2, Padang Rajo 2; LA, Lubuk Alung; PR1, Padang Rajo 1.
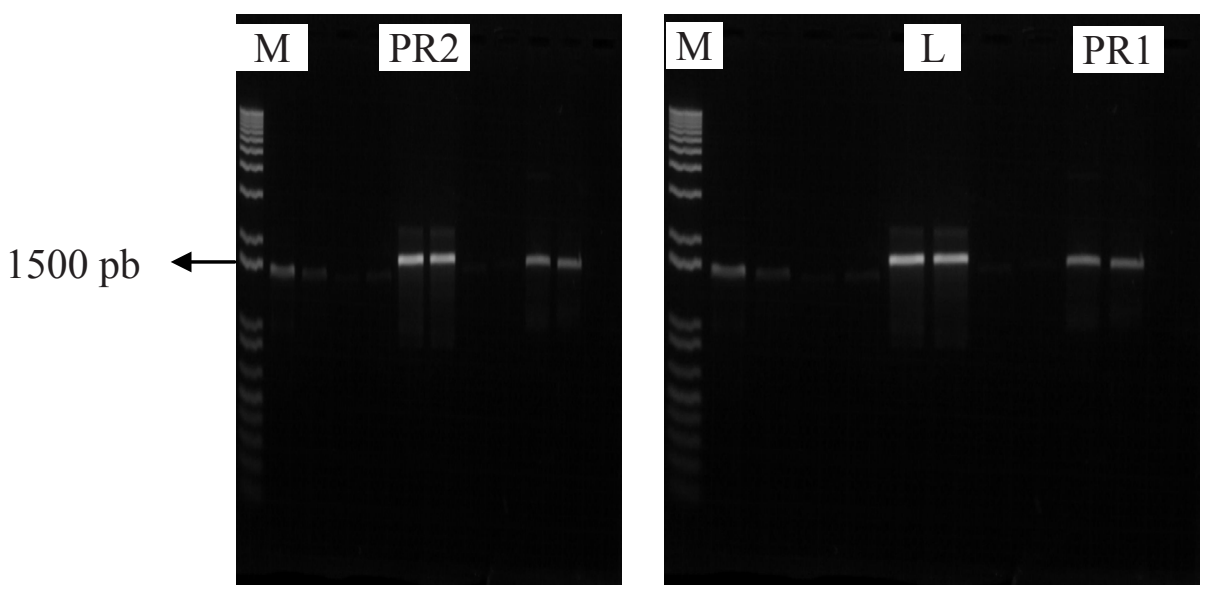

Gambar 3 Hasil amplikasi beberapa isolat bakteri menggunakan primer 16S rNRA/ITS. M, 1 kb penanda DNA; PR2, Padang Rajo 2; LA, Lubuk Alung; PR1, Padang Rajo 1. 
Salah satu medium yang dapat digunakan untuk identifikasi bakteri genus Pantoea adalah medium Hugh-Leifson (HL), medium ini digunakan untuk mengetahui isolat yang mampu menghasilkan glukosa secara anaerobik (fermentasi). Pada tabung yang diberi vaseline, goresan isolat berwarna kuning artinya isolat bereaksi positif $(+)$.

Bakteri Gram negatif tertentu menghasilkan signal dalam bentuk substitusi acyl homoserine lactone (acyl-HSLs) yang dikenal dengan autoinduser. Pesan-pesan ini memungkinkan populasi bakteri memonitor kepadatannya sendiri (querum sensing) untuk menggerakkan, mengkoordinasikan, dan menyatukan respons ketika ada kesempatan memarasit inang (Bodman dan Farrand 1995). Dalam pengujian deteksi AHL, hanya isolat PT1 dan PT3 yang tidak menghasilkan AHL. Dalam hal ini kemungkinan kedua isolat ini tidak bersifat patogen meskipun keduanya bersifat Gram negatif.

Deteksi EPS stewartan dilakukan untuk mengetahui kemampuan isolat dalam menghasilkan stewartan. Jumlah stewartan yang dihasilkan berkaitan dengan kemampuan isolat dalam menimbulkan gejala water soaking pada inang. Virulensi dari mutan $P$. stewartii mampu menyebabkan water soaking pada daun, juga mampu menyebabkan gejala layu sehingga diduga EPS merupakan faktor virulensi dari mutan ini. Demikian juga Minoque et al. (2005) menyatakan bahwa ekspresi EPS bergantung pada kepadatan sel bakteri yang akan menentukan perkembangan layu stewart. Koloni yang menghasilkan EPS bersifat kental, seperti lumpur, fluidal, dan permukaannya berlendir, sedangkan koloni yang kurang menghasilkan EPS bersifat tidak berlendir dan halus seperti krim (Bodman dan Farrand 1995).

Uji adhesi dilakukan untuk mengetahui lendir yang dihasilkan oleh bakteri. Semakin banyak lendir yang dihasilkan berarti semakin tinggi kemampuan bakteri untuk menempel pada inang. Bakteri uji ini menghasilkan mukus, yang menyumbat pembuluh vaskuler tanaman jagung sehingga akhirnya tanaman layu dan mati. Adanya adhesi pada bakteri merupakan langkah penting dalam menentukan apakah bakteri bersifat parasit atau simbiotik (Koutsoudis et al. 2006).

Berdasarkan semua uji yang dilakukan, hanya 7 isolat, yaitu KP1, PT1, PR1, PP, LA, PT3, dan PR2 yang tergolong pada famili Enterobacteriaceae. Namun setelah dilakukan uji PCR, ternyata isolat PT1, PP, dan PT3 tidak tergolong ke dalam genus Pantoea, hal ini kemungkinan terjadi kesalahan dalam pengujian metabolisme glukosa.

\section{UCAPAN TERIMA KASIH}

Penelitian ini merupakan sebagian dari penelitian Hibah Bersaing yang dibiayai oleh DIPA Kopertis Wilayah X dengan Kontrak No. 0666/023-04.2.01/03/2012 tanggal 9 Desember 2011.

\section{DAFTAR PUSTAKA}

Bodman SB, Farrand SK. 1995. Capsular polysaccharide biosynthesis and pathogenicity In Erwinia stewartii require induction by An $\mathrm{N}$-acylhomoserine lactone autoinducer. J Bacteriol. 177:5000-5008.

EPPO Buletin. 2006. Diagnostics antoea stewartii subsp. stewartii. Eur Med Plant Protect Org. 36(1):111-115.

Koutsoudis MD, Tsaltas D, Minoque TD, Suzanne VB. 2006. Quorum sensing regulation governs bacterial adhesion, biofilm development, and host colonization in Pantoea stewartii subsp. stewartii. Proc Natl Acad Sci. 103(15):5983-5988. DOI: http://dx.doi.org/10.1073/pnas.0509860 103.

Minoque TD, Carlier AL, Koutsoudis MD, Suzanne VB. 2005. The cell densitydependent expression of stewartan exopolysaccharide in Pantoea stewartii ssp. stewartii is a function of EsaRmediated repression of the rcsA gene. Molecular Microbiology. 56(1):189-203. DOI: http://dx.doi.org/10.1111/j.1365-2958. 2004.04529.x

Rahma H. 2013. Kajian penyakit layu stewart pada jagung (Pantoea stewartii subsp. 
stewartii dan upaya pengendaliannya [disertasi]. Bogor (ID): Institut Pertanian Bogor.

Taylor WI,AnhanzarD. 1972. Catalase testas an aid to identification of Enterobacteriaceae. App Microb. 24(1):58-61.

[TAS] Thai Agricultural Standard. 2008. Diagnostic Protocol for Pantoea stewartii subsp. stewartii Bacterial Wilt of Maize. Bangkok (TH): National Bureau of
Agricultural Commodity and Food Standards Ministry of Agriculture and Cooperatives.

Trisnawati F. 2010. Tingkat serangan Pantoea stewartii subsp. stewartii pada berbagai fase hawar dan layu stewartii pada jagung (Zea mays L.) di Kabupaten Pasaman Barat [skripsi]. Padang (ID): Universitas Andalas. 